\title{
The Role of Oral Traditions in Ecotourism Conservation in Indonesia and Japan
}

\author{
Maharani Patria Ratna ${ }^{1 *}$, Girindra Putri Ardana Reswari ${ }^{2}$, Fitri Alfarisy ${ }^{3}$, and Ressa \\ Meyyana Dewi ${ }^{4}$ \\ 1,2,3,4Applied Foreign Languages, Vocational School, Diponegoro University
}

\begin{abstract}
As a background of this research, the oral tradition is an ancestral heritage that influences various aspects of a society's life as an identity of local wisdom. Apart from containing moral messages, oral traditions are often linked to the original character. Also, oral traditions cannot be separated from their role in the tourism industry. Many tourist objects are offered because they have fascinating oral traditions to attract tourists. The role of oral traditions in the tourism industry should be mapped to develop various sectors. This study aims to identify the role of oral traditions in developing ecotourism in Indonesia and Japan. The method used in this research is literature study and interviews. The result shows that in Indonesia and Japan, oral traditions still immensely attract tourists to come to the tourist spot. Many tourists who come to ecotourism spots want to enjoy vacation or to recover from any disease. This condition makes the government and the local civil conserve their ecotourism spot. In conclusion, this study indicates four roles of oral traditions in the development of ecotourism, namely as a means of attracting tourists' interest, as a means of developing tourist areas, as a means of developing tourism products, and as a means of developing human resources.
\end{abstract}

\section{Introduction}

Ecotourism is one of the environmentally friendly tourism activities by prioritizing aspects of nature conservation, socio-cultural-economic empowerment of local communities, and learning and education. Not infrequently, the existing ecotourism is always shaded by an oral tradition that has been inherent in society since time immemorial. The oral tradition in ecotourism is also often the selling point of a tourist destination to attract visitors. In the field of tourism, oral tradition is one of the attractions in branding tourist attractions. In the modern era, the oral tradition has become easier for many people to know, not just the local community. By the name, oral tradition is conveyed orally from generation to generation. Because it was conveyed orally, there are generally several versions in the oral tradition. This is, of course, because in the delivery of oral messages, there are times when the recipient of the message has different perceptions in the delivery.

\footnotetext{
* Corresponding author: maharanipatria@live.undip.ac.id
} 
Research on oral traditions that have been carried out before includes Erfinawati and Ismawirna [1] and Yogyanti [2]. Erfinawati wrote about the cultural values of oral literature of the Aceh Jaya community, which were obtained from four female informants and one male informant. The results of this study are the cultural values in the oral literature of the Aceh Jaya community, including memories, customary regulations regarding applications, and historical matters. Meanwhile, Yogyanti examines the ins and outs of sarumawashi (Monkey Mask) in Japan from a tourism point of view. This research shows that sarumawashi, which has existed for thousands of years in Japan, has a historical value that cannot be separated from the socio-cultural Japanese society, which is related to the belief system and the hierarchical system of society.

The difference between this study and the research conducted by Erfinawati and Ismawirna is that this research focuses on the role of oral tradition. In contrast, Erfinawati and Ismawirna's research focuses on cultural values in oral literature or oral traditions. On the other hand, research conducted by Yogyanti discusses the use of oral traditions for the preservation of arts in Japan. In contrast, this study discusses the description of the role of oral traditions in ecotourism conservation. In general, this study aims to identify the role of oral traditions in developing ecotourism in Indonesia and Japan. This research is expected to reaffirm the role of oral traditions in the development of ecotourism. Ecotourism was chosen as a tourism sub-sector in this study as a form of support for the SDG (Sustainable Development Goals) program launched by the government to encourage public awareness of nature conservation, which can be an alternative source of livelihood for local communities.

\section{Methods}

According to Sugiyono [3], descriptive research is a study conducted to determine the value of the independent variable, either one or more (independent) variables, without making comparisons or connecting with other variables. Meanwhile, according to Saryono [4], qualitative research is used to investigate, find, describe, and explain the quality or features of social influences that cannot be explained, measured, or described through a quantitative approach. Based on the definitions and descriptions of this research, it can be understood that this research is included in qualitative descriptive research because it is carried out by describing the phenomenon of particular objects descriptively. There are three stages in conducting this research: data collection, data analysis, and presentation of results. In this study, data were collected through interview and literature study methods.

After the data is collected, the next step is data analysis. Data analysis was carried out in three stages to each answer the problem formulations, namely describing the role of oral traditions in ecotourism conservation in Indonesia, describing the role of oral traditions in ecotourism conservation in Japan, and based on these two things, identifying the role of oral traditions in ecotourism conservation. In Japan and Indonesia. Data processing was carried out in interviews and literature studies to analyze the role of oral traditions in ecotourism conservation in Indonesia. As a sample to observe the role of oral traditions in the conservation of ecotourism in Indonesia, interviews were conducted with resource persons from tourism villages in Indonesia, namely the tourist village of Kandri. Apart from interviews, a literature study was also conducted on oral traditions in ecotourism conservation in Indonesia. 
Meanwhile, it is carried out based on the previous description to identify the role of oral traditions in conserving ecotourism in Indonesia and Japan. The next stage is the stage of presenting the research results. In this stage, a description of the role of oral traditions in the conservation of ecotourism in Indonesia will be simplified to answer the formulation of the problem in this study.

\section{Result and Discussion}

The term oral tradition refers to stories that have been passed down from generation to generation by a community. Apart from being passed down from generation to generation, oral traditions sometimes have slightly different versions in society and contain mythical things that are the beliefs of the local community. In the tourism sector, oral traditions are often at the forefront of tourism promotion to attract tourists. In general, this happens in the promotion of ecotourism. Ecotourism with a background in oral traditions circulating in the community will become a tourist attraction.

\subsection{The Role of Oral Traditions in Ecotourism conservation in Indonesia}

As a country full of cultural diversity, various regions in Indonesia are known to have preserved oral tradition. The following are some of ecotourism in Indonesia that are known for their oral traditions:

\section{Telaga Warna}

Telaga Warna is located in the tourist area of Dieng. This lake is known for its watercolour changing to red, yellow, blue. There are several oral traditions in the community regarding the lake of colours, one of which is that there used to be a queen and a princess who would bathe in the lake. However, after taking off their clothes, the clothes flew in the wind to cover the entire lake. This makes the water in Telaga Warna can change colour until now. Various versions of the oral tradition regarding the lake of colours and its uniqueness make tourists want to see closely and prove the changes in water in Telaga Warna, which rarely occur in water in other lakes in general [5].

\section{Spring of Gede}

Spring of Gede is one of the tourist attractions in the village of Kandri, Central Java. "Gede" pinned into the name of this sendang means "big." There is a spring so big that it is feared that it will become a swamp and drown the village. Therefore, the elders of the village of Kandri had previously made a buffalo head to minimize the flow of water. After the water was $^{i}$ minimized, several irregularities occurred in the Gede spring, so that the local community agreed to prohibit anyone from crying, washing household furniture, and berating whatever was around the spring. This oral tradition is one of the selling points of Kandri village so that it gets the title of a Kandri tourist village because it has many springs with fascinating oral traditions [6].

\section{Lake of Toba}

Lake Toba has become one of the tourist icons in Indonesia. Apart from its beauty, Lake Toba's legendary oral tradition is one its selling points, so its conservation continues to be encouraged by the government until now. In the promotion of Indonesian tourism, the existence of Lake Toba is often the main selling point that appears in various Indonesian tourism booklets and has been translated into various languages in the world. The 
surrounding community and the oral tradition about Lake Toba have been passed down from generation to generation throughout Indonesia. Lake Toba is believed to have originated from a natural disaster caused by a man named Toba who had broken his oath by mentioning the origin of his wife, who was a daughter who turned into a goldfish [7].

\section{Spring of Jambu}

Spring of Jambu is located at the tourist village of Kandri, Semarang. The Semarang city government continues to intensify the promotion and conservation of ecotourism in the tourist village of Kandri as a tourist asset. Besides the Gede spring, the Jambu spring is the main attraction of the Kandri tourist village because this spring is believed to cure various diseases. Some tourists who visit the tourist village of Kandri aim for tourism and aim to try and prove the properties of water in the Jambu spring based on oral traditions circulating in the community. In the oral tradition, it is said that the state of the water from the Jambu spring can adjust to the body temperature of the person using it. If the person who bathes in this spring has a cold body temperature, the water in the spring will change to a warm temperature, and vice versa. To use the water in the Jambu spring for medicinal purposes, the community believes that bathing should be done after midnight with the permission of the spring guard [8].

\section{Tangkuban Perahu Mountain}

Similar to Lake Toba, Mount Tangkuban Perahu is also known to foreign countries. Conservation of Mount Tangkuban Perahu is carried out by the government and all levels of society. Of course, not only by promoting the beauty of Mount Tangkuban Perahu but also by carrying out its oral traditions. The oral tradition of Tangkuban Perahu makes tourists both from within and outside the country flock to see the mountain, which is said to have a shape similar to an overturned boat. The oral tradition about the origin of Tangkuban Perahu Mountain tells of Sangkuriang, who fell in love with the lady of Sumbi, his mother. When Sangkuriang wanted to marry his mother, Dayang Sumbi gave a condition that required him to build a boat and lake in one night. However, his attempts failed. Disappointed, Sangkuriang kicked the boat to capsize and is said to have become Mount Tangkuban Perahu [9].

\subsection{The Role of Oral Traditions in Ecotourism conservation in Japan}

The following are some examples of ecotourism destinations in Japan that their conservation cannot be separated from the role of oral tradition:

\section{Fuji Mountain}

Fuji Mountain is a Japanese tourist icon that has been known to the world for a long time. Oral traditions about Mount Fuji make people of the world interested in seeing its beauty. In the past, people believed that women were not allowed to visit Mount Fuji because it was feared that the fire goddess who lived on Mount Fuji would be jealous of the beauty of other women. Gradually in the 1860 s, women were allowed to visit Mount Fuji. The Japanese government conserves Mount Fuji by promoting Mount Fuji as one of Japan's leading tourist destinations.

\section{Lake of Tazawa}

Lake of Tazawa is the deepest lake in Japan. The oral tradition about Lake Tazawa is that a wonderful young woman lived on a mountain long ago. She wanted to keep her beauty forever, so she prayed to the goddess Kwan-Im. On the night when his wish was about to be 
fulfilled, he was told by the goddess Kwan-Im to cross to the northern mountain, then drink from the spring there. He did precisely as the goddess said and found a magical spring. Then he drank a little water but suddenly felt his thirst getting stronger and stronger, so he drank too much of the water. The woman continued to drink with all her energy, and before she realized it, she had turned into a giant dragon. The mountain where he lived collapsed with a great roar, forming a deep lake. The lake was then called Lake Tazawa. The woman is still believed to live in the lake as a dragon.

\section{Miho Pine Forest}

Apart from Mount Fuji, Japan is also known for its Miho pine forest tourist destination. Japanese people believe that the Miho pine forest is where the famous Japanese legend, Hagoromo, occurred. Long ago, dancers from heaven removed their hagoromo, or "fur cloak", into the world. A fisherman finds it and asks the dancer to dance if he wants the robe back. The fisherman was stunned when the angel danced and then slowly flew back to heaven. Conservation of the Miho pine forest is not only carried out by the Japanese government, but UNESCO has also determined that the Miho pine forest is one of the world heritages sights as part of Mount Fuji.

\section{Hamamura Hot Spring}

Hot springs are abundant in Japan. One of them is the Hamamura hot springs. The Japanese believe that bathing in hot springs can cure ailments. This is based on an oral tradition that circulates about a stork who was injured completely healed after soaking in a spring which gave them the nickname Stork's Spring. Although scientifically, Hamamura hot springs are known to be rich in minerals to cure illnesses [10].

\section{Nachi Falls}

Nachi Falls is the highest waterfall in Japan. According to oral traditions circulating in the community, Shintoists believe that the water at Nachi Falls benefits longevity. In addition, it was believed in ancient times that the imperial family and aristocrats often went on spiritual journeys to the Nachi Falls. Like the Miho pine forest, the Nachi waterfall has also been recognised by UNESCO as a world heritage site. Currently, the Japanese government is actively pursuing the conservation of Nachi Falls, considering that Nachi Falls are known for their natural beauty and oral traditions and because Nachi Falls has become a spiritual tourism spot for the public.

\subsection{Identification of the Role of Oral Traditions in Ecotourism Conservation in Indonesia and Japan}

Indonesia and Japan are countries located in Asia. Both have oral traditions that are passed down from generation to generation. The existing oral traditions often become an attraction for ecotourism to be sold to foreign countries. Based on the description of the role of oral traditions in the conservation of ecotourism in Indonesia and Japan, respectively, it can be understood that the role of oral traditions in ecotourism conservation in Indonesia and Japan based on Sudardi et al.'s [11] theory is as follows:

1. Oral traditions as a medium for ecotourism attraction

Based on the description above, it can be understood that oral tradition is one of the factors that can attract tourists to visit ecotourism destinations [12]. Many tourists feel curious by seeing tourist objects closely and hearing the oral traditions of the local community directly. An example is the tourist attraction of the lake of colours and the hot springs of Hamamura. Many tourists are interested in visiting the lake of colours to witness the change in the colour 
of the Telaga Warna water. In addition, the benefits of water in Hamamura hot springs are also an attraction for tourists who come to cure illnesses.

\section{Oral tradition as a medium for developing tourist areas}

The circulation of oral traditions that are the main attraction of a tourist destination especially ecotourism - will indirectly develop tourist destination areas. With tourist destinations, investors are more interested in building hotels or restaurants in the surrounding area. This certainly makes tourist areas more developed and crowded, especially in ecotourism destination areas that generally require support for tourist areas in various aspects. Not only hotels and restaurants but also infrastructure. Unlike in Japan, in Indonesia, ecotourism destinations generally have the inadequate infrastructure; this is, of course, a shared task - especially the government - as a form of support for tourism development in Indonesia [13].

3. Oral traditions as a medium for developing tourism products

Oral traditions that attract tourists to ecotourism destinations will make tourists visit tourist objects and buy souvenirs as mementoes. Tourism products produced to be sold as souvenirs can be in the form of t-shirts, hats, knick-knacks, Etc. Various innovations regarding the diversification of tourism product development continue to develop into various types of products. Tourists will purchase a simple product that reads a tourist attraction as evidence or a memento that they have been to a tourist destination. For example, in mountain ecotourism destinations, many knick-knacks are sold to meet the needs of tourists to climb mountains with the names of specific tourist destinations written on them [14].

4. Oral traditions as a medium for developing Human Resources

Human Resources (HR) is the main driving force for the development of ecotourism destinations. People who work together to build their tourist areas and equip themselves with various skills to facilitate the needs of tourists have indirectly developed the community's human resources. The community's oral traditions continuously preserved are the link in the chain of developing human resources with local wisdom [15]. As a form of readiness to welcome foreign tourists, for example, people will be motivated to equip themselves with foreign language skills that can facilitate foreign tourists and convey oral traditions, which are the main attractions of tourism, especially in ecotourism destinations. In addition, armed with other skills, especially in the diversification of tourism products, will become a forum for human resource development.

\section{Conclusion}

Based on the description above, it can be understood that there are four essential roles of oral tradition in ecotourism development, namely oral tradition as a medium for ecotourism attraction, oral tradition as a medium for developing tourism areas, oral tradition as a medium for developing tourism products, and oral tradition as a medium for developing human resources. In general, ecotourism in Japan has received more international attention from the local community and the government to improve the situation. Unlike in Indonesia, ecotourism destinations have not received widespread attention from both the public and the government. A simple example can be seen in terms of the cleanliness of ecotourism destinations. Departing from the awareness of Japanese people who are reluctant to litter, ecotourism destinations are kept clean. These contrasts ecotourism destinations in Indonesia, which are still improving their management to be a clean ecotourism destination. 


\section{References}

1. I. Erfinawati, Nilai budaya dalam sastra lisan masyarakat ache jaya, Jurnal Bahasa dan Sastra, 81-89 (2019)

2. D. W. Yogyanti, Strategi pengembangan kesenian sarumawashi (Topeng Monyet), Jurnal Khasanah Ilmu, 57-64 (2017)

3. Sugiyono, Metode penelitian kuantitatif, kualitatif dan $R \& D$, (Alfabeta Bandung, 2013)

4. Saryono, Metode penelitian kualitatif, (Alfabeta Bandung, 2010)

5. E. Suhaeni, Misteri telaga warna, (Badan Pengembangan dan Pembinaan Bahasa Bogor, 2009)

6. Buku Profil Desa Wisata Kandri. (n.d.). Semarang, Central Java, Indonesia.

7. A. A. Widhijanto, E. Y. Tisnaningtyas, Identifikasi kawasan permukiman. pendukung: Analisis proximity pengembangan destinasi Wisata Danau Toba, Jurnal Neo Teknika, 4(1), 11-19 (2018)

8. Masduki. (2021, 5 2), (M. P. Ratna, Interviewer) (2021)

9. K. Anwar, Oral Tradition (Literature): Conservation of Ecology and Promotionof Tourism Destination, Magistra Andalusia: Jurnal Ilmu Sastra, 1(1), (2019)

10. Buku Panduan Wisata. (n.d.), Sisi baru dari Jepang, Tottori.

11. B. Sudardi, S. Supana, A. Y. Wirajaya, (2007), Pemanfaatan tradisi lisan dieng untuk pengembangan pariwisata. Retrieved from https://lppm.uns.ac.id/id/2009/01/29/pemanfaatan-tradisi-lisan-dieng-untukpengembangan-pariwisata/

12. A. A. P. Wiranata, Pengunaan jenis bahasa serta interaksi komunitas pedagang asongan dengan wisatawan mancanegara Di Kawasan Wisata Pantai Kuta, Jurnal Destinasi Pariwisata, 123-126 (2016)

13. A. S. Moerwanto, K. Pekerjaan, Infrastruktur wisata terintegrasi sambutan Menteri Pariwisata Republik Indonesia pada peringatan world tourism day dan Kementerian Pekerjaan Umum dan Perumahan Rakyat, melalui Direktorat Jenderal. 3(2), 67-78 (2017)

14. I. Safitri, A. Ramdan, E. Sunarya, Peran produk wisata dan citra destinasi terhadap keputusan berkunjung wisatawan, Jurnal Ilmu Manajemen, 734-741 (2020)

15. H. Widyastuti, Pemanfaatan cerita tradisi lisan untuk pengajaran BIPA, 1151-1166 (2017) 